\title{
Consumer Guilt Review: A Practical Guide for Researchers
}

Ghadeer G. Kayal

Fabian Way, Swansea, SA1 8EN, UK

Email: g-kayal@windowslive.com

Phone: (+44)1792-809727

First author

Nripendra P. Rana*

Fabian Way, Swansea, SA1 8EN, UK

Email: nrananp@gmail.com

Phone: (+44)1792-295179

*Corresponding Author

Antonis C. Simintiras

P.O. Box 7207 Hawally,

32093 Kuwait

Email: Simintiras.A@gust.edu.kw

Phone: (+965) 25307333

Co-author

Ghadeer Kayal is a $\mathrm{PhD}$ candidate at the School of Management of Swansea University in the UK. Her research aims to improve the understanding and measurement of guilt experiences in the consumer behaviour domain. She has presented her work in couple of conferences and recently published a peer reviewed journal article in this area of research.

Nripendra P. Rana is an associate professor in the School of Management at Swansea University, U.K. With an academic and professional background in Mathematics and Computer Science and with PhD in Information Systems, his current research interests focus primarily upon adoption of emerging and cutting-edge technology, e-government, mgovernment, e-commerce and m-commerce systems. His work has been published in leading academic journals including European Journal of Marketing, Information Systems Frontiers, Government Information Quarterly, Production Planning \& Control, Journal of Business Research, Public Management Review and Computers in Human Behaviour. He has also presented his research in some of the prominent international conferences of information systems across the world.

Antonis C. Simintiras is currently the dean at the College of Business Administration - Gulf University for Science and Technology in Kuwait, and a research professor of Marketing at the School of Management - Swansea University, UK. His research interests are, amongst others, in the areas of personal selling and sales management, consumer behaviour and cross-cultural research methodology. He has published widely and co-authored two books. 


\begin{abstract}
A systematic review of the literature of guilt in consumer behavior revealed a lack of diversity in respect of various factors that affect the elicitation of guilt-induced behavior. These factors are the cause of guilt (self, society, others/action, inaction); the form in which guilt manifests (anticipatory, reactive, existential); and moderators (culture, demographics, narratives). Implicitly, the review illustrated that researchers exhibit a tendency towards assessing reactive guilt caused by the self in individualistic cultures. Such findings cannot be generalized to encompass other forms of guilt that had alternate causes, nor be applied in collectivist cultures. Such considerations are imperative, due to guilt's inherent complexity. Therefore, this review provides a guide for future research based on these factors, and introduces e-guilt, as sufficient evidence suggests that online settings present incomparable circumstances where one's behavior is visible and irretrievable.
\end{abstract}

Keywords: Guilt, Consumer behavior, Review, Consumption, Consumer guilt

\title{
Introduction
}

Consumer behavior scholars have been asking for more research that examines guilt in consumption, as guilt is a significant emotion that is used by marketers to regulate and motivate consumers' behavior. Indeed, research that examines guilt in consumption has gained significant momentum in the past few years (Antonetti \& Baines, 2015). Still, there are many research gaps that are yet to be explored, which were emphasized by extant research (Antonetti \& Baines, 2015). This lack of research can be attributed to the complexity of guilt itself, as it requires an individual to actively process a series of cognitive appraisals (Antonetti \& Maklan, 2014b; Soscia, 2007; Tracy \& Robins, 2004). In addition, due to the negative nature of guilt, researchers are always confronted with ethical concerns that hinder the progress of guilt-related research in consumption (Antonetti \& Baines, 2015). Moreover, to examine guilt in consumption, numerous complex decisions have to be accurately made. For instance, guilt can manifest in different forms (i.e., anticipatory, reactive, and existential), and it does not necessarily emerge as a result of one's actions, but also as a result of one's inactions (Cotte, Coulter, \& Moore, 2005; Dahl, Honea, \& Manchanda, 2003). In addition to the need to include a narrative that not only represents a distinct manifestation of guilt but also has the potential to 
activate the complex cognitive appraisals needed for its elicitation (Lee-Wingate \& Corfman, 2010; Soscia, 2007).

Further, feelings of guilt in consumption are found to differ significantly between genders (Hanks \& Mattila, 2014; Kayal, Simintiras, \& Rana, 2017) and cultures (Onwezen, Bartels, \& Antonides, 2014a). Thus, studies that do not take into consideration these aspects may compromise the validity of their findings. For example, having more females than males in a sample may increase the level of guilt, and thus the results might lead to either type I or type II errors. This is likely to occur in individualistic cultures, as research indicates that in collectivist cultures, gender differences in guilt are not prominent (Kayal et al., 2017). Taking that into consideration, this review argues that the nature of guilt-induced behavior largely depends on three factors: agency or cause (self, society, others/action, inaction); the form in which guilt manifests (i.e., anticipatory, reactive, and existential); and moderating factors (culture, demographics, narrative) (Figure 1). Therefore, future researchers might benefit from a practical guide that entails guidelines to assessing guilt-induced behavior in consumption.

Notably, previous reviews that examine guilt in marketing provide significant insight into research findings (Antonetti \& Baines, 2015). Therefore, this review does include the outcomes of recent publications; however, its primary focus is on identifying problematic issues relevant to examining guilt in consumer behavior and to provide guidance for future research. Accordingly, to attain the aim of this review, this study begins by specifying the review criteria followed by a brief recount of the definition, classification, functions, and appraisals of guilt. After that, the review provides a distinct classification of the contexts that examine guilt in consumption and assesses the characteristics and findings of these contexts. Subsequently, the review inspects the narratives and product categories used by researchers to elicit guilt. Next, the review considers the methodological approaches of previous publications in terms of the sample characteristics and procedures, research methods, measurement scales, and analysis. 
Then, the review moves on to discuss prominent findings and provide future researchers with guidelines that are imperative when examining consumer guilt. Additionally, the discussion progresses to highlight the lack of research that examines guilt in online consumer behavior. Therefore, this review rationalizes the distinctive circumstances of online settings that might affect the experience and severity of guilt.

\section{Review criteria}

This review's key objective is to assist researchers in making informed decisions when investigating consumer guilt. Therefore, a systematic review of guilt-related research in consumer behaviour was conducted, using only the Academic Journal Guide (2015) of the Association of Business Schools (ABS). Specifically, the review included papers from the highest-ranked journals in ABS such as the Journal of Consumer Research, the Journal of Marketing, the Journal of Consumer Psychology, Psychology \& Marketing, European Journal of Marketing, and Marketing Theory. Of note, journals from lower ranks were also used based on their contribution to the area of interest to this review. We used the following keywords in the Web of Science Data Base (Core Collection): consumption guilt, consumer guilt, and guilt in the topic of consumer behavior. The time-line incorporated studies that have been published since the conception of consumer guilt by (Lascu, 1991) to the year 2017. The systematic review incorporated publications from journal articles only; papers that were published in conference proceedings were not included in the review. In addition, papers that focus on guilt in the advertising domain were acknowledged when necessary but largely excluded, as they mainly focus on instances that involve the employment of guilt appeals. After applying the exclusion criteria, and further examination of other publications in other fields, as the majority of guilt-related literature is found in psychology and social psychology, a total of 60 publications were used in this review. 


\section{Guilt: definition, functions, and classification}

Baumeister, Stillwell, and Heatherton (1994) defined guilt as “an individual's unpleasant emotional state associated with possible objections to his or her actions, inaction, circumstances, or intentions". These objections stem from violating the individual's ethical and social standards (Kugler \& Jones, 1992). Hence, such feelings leave a person in a restless emotional state, which motivates the individual to alleviate those feelings by repairing his or her behavior, confessing, or asking for forgiveness (Tangney, Miller, Flicker, \& Barlow, 1996). Despite the negative nature of guilt, it has functional benefits as it drives a person to acknowledge the cause of the wrongdoing, and thus attempt to rectify it (Lewis, 1997; Tracy \& Robins, 2006). Accordingly, researchers constantly emphasize the ability of guilt not only to motivate one's behavior but also to regulate it, as individuals monitor and adjust their actions to reflect their personal values and goals (Tangney, Stuewig, \& Mashek, 2007).

Guilt can be classified as an emotional state and a personality trait (Kugler \& Jones, 1992). Guilt as an emotional state refers to instances where an individual experiences guilt in a specific moment (Cohen, Panter, \& Turan, 2012), whereas guilt as a personality trait is an indication of an individual's proneness to experience guilt (Cohen, Panter, \& Turan, 2013). Guilt as an emotional state can be further classified into anticipatory, reactive, and existential. First, anticipatory guilt emerges in circumstances where an individual thinks of a potentional transgression that does not adhere to his or her personal values or standards (Cotte et al., 2005). Second, reactive guilt is a result of a person's morally inferior behavior that contradicts that person's values (Burnett \& Lunsford, 1994; Steenhaut \& Van Kenhove, 2006). Third, Mattila, Hanks, and Zhang (2013) stated that "individuals can experience existential guilt when they feel that they have been the recipients of rewards, benefits, or good fortune that other, equally worthy, people do not receive". Accordingly, these identified manifestations of guilt are the result of a succession of cognitive appraisals, which are discussed below. 


\section{Appraisals of guilt}

Lazarus (1991) states that an appraisal incorporates an evaluation of the significance of what is occurring in a specific situation. With respect to guilt, it is elicited as a result of a progression of cognitive appraisals (Tracy \& Robins, 2004). Established research in psychology exemplifies that guilt emerges as a result of the following cognitive appraisals. In a certain event, an individual has to determine that the event is significant, appraise that it is incompatible with the individual's identity goals, and determine that the event was caused by local attributions (Tracy \& Robins, 2004). Lewis (1997) had similar views on the appraisals required to elicit guilt. For instance, Lewis (1997) proposes a somewhat comparable process of the cognitive appraisals of guilt. However, Lewis (1997) emphasizes the importance of the development of one's standards, rules, and goals. Indicating that there is a certain age where such values develop, and children younger than three years old may not be able to feel guilt (Lewis, 1997). These appraisals represent a sequential process, as each appraisal is imperative for guilt to emerge (Tracy \& Robins, 2004).

\section{Consumer guilt in consumption domains}

Researchers acknowledge the importance of utilizing guilt in marketing practices (Antonetti \& Baines, 2015). In particular, guilt is employed by marketing practitioners primarily in the advertising and consumer behavior domains (Antonetti, Baines, \& Walker, 2015). With respect to consumer behavior, consumer guilt is experienced when consumption episodes do not coincide with the consumer's personal, societal, or social values (Dahl et al., 2003). Thus, consumer guilt can be categorized based on the cause of the transgression, whether it is caused by the self, society, or others (Dahl et al., 2003). Notably, in those consumption situations, consumers' actions or inactions can result in consumer guilt (Dahl et al., 2003). Furthermore, Burnett and Lunsford (1994) also proposed a classification of consumer guilt, which entails financial guilt, social responsibility guilt, health guilt, and moral guilt (Table 1). 
Table 1: Various classifications of guilt

\begin{tabular}{|c|c|c|}
\hline Term & Categories & Source \\
\hline Classification of guilt & $\begin{array}{l}\text { Personality trait } \\
\text { Emotional state }\end{array}$ & Kugler and Jones (1992) \\
\hline $\begin{array}{l}\text { Classification of guilt as an } \\
\text { emotional state }\end{array}$ & $\begin{array}{l}\text { Anticipatory } \\
\text { Reactive } \\
\text { Existential }\end{array}$ & $\begin{array}{l}\text { Cotte et al. (2005) } \\
\text { Burnett and Lunsford (1994) } \\
\text { Steenhaut and Van Kenhove } \\
\text { (2006) } \\
\text { Mattila et al. (2013) }\end{array}$ \\
\hline Categories of consumer guilt & $\begin{array}{l}\text { Guilt related to the self } \\
\text { Guilt related to society } \\
\text { Guilt related to others }\end{array}$ & \multirow[t]{2}{*}{ Dahl et al. (2003) } \\
\hline Subcategories of consumer guilt & $\begin{array}{l}\text { Guilt as a result of consumers' } \\
\text { actions } \\
\text { Guilt as a result of consumers' } \\
\text { inactions }\end{array}$ & \\
\hline $\begin{array}{l}\text { Alternate classification of } \\
\text { consumer guilt }\end{array}$ & $\begin{array}{l}\text { Financial guilt } \\
\text { Social responsibility guilt } \\
\text { Health guilt } \\
\text { Moral guilt }\end{array}$ & Burnett and Lunsford (1994) \\
\hline
\end{tabular}

Research provided sufficient evidence that different contexts may have a distinct function of guilt (Onwezen, Bartels, \& Antonides, 2014b). When examining the literature of consumer guilt, four distinct contexts were identified: pro-environmental behavior, everyday consumption, hedonic and impulsive consumption, and travel and hospitality. Significant similarities and patterns are observed within each context. For example, researchers (Onwezen et al., 2014b; Steenhaut \& Van Kenhove, 2006), in the context of pro-environmental behavior, often applied the theory of planned behavior (Ajzen, 1991) as a foundation for their research and conceptual frameworks. Therefore, the majority of research in this context examined identical variables and reached similar conclusions. In view of that, the following subsections are distinguished based on these contexts.

\section{Pro-environmental consumer behavior}

Pro-environmental behavior (PEB) refers to "behavior that consciously seeks to minimize the negative impact of one's actions on the natural and built world (e.g., minimize resource and energy consumption, use of non-toxic substances, reduce waste production)" (Kollmuss \& Agyeman, 2002). The majority of research concerning guilt in consumption is found in the 
context of PEB. This can be attributed to guilt's moral function, as it arises as a result of selfreflection in reference to one's standards and values (Tangney et al., 2007); hence, it offers a motivational force that drives individuals to do good and dissuades them from doing bad (Kroll \& Egan, 2004).

Moreover, guilt motivates individuals to engage in reparative behavior as a coping mechanism to alleviate this feeling (Tangney et al., 2007). For instance, a consumer who experiences guilt as a result of his/her failure to recycle would attempt to repair this behavior in the future and try to recycle (Antonetti \& Maklan, 2014b). To assess this context, research that examines consumer guilt in relation to pro-environmental consumer behavior is assessed, specifically, research that describes ethical, sustainable, or green consumer behavior. Furthermore, the assessment incorporates reporting major findings in relation to consumer guilt in terms of its influence, theoretical applications, types, narratives, and methodology.

The majority of research affirms the impact of guilt on regulating consumers' proenvironmental intentions and behaviors (Table 2). Specifically, guilt is found to have a direct impact on consumers' intentions to engage in sustainable consumption (Antonetti \& Maklan, 2014b) such as their intention to buy organic food (Onwezen et al., 2014a, 2014b), as well as ethical products (Antonetti \& Maklan, 2014a). Notably, guilt's effect on consumers' intentions, with varying degrees, is present in both individualistic and collectivist countries (Onwezen et al., 2014a). Furthermore, the examined literature emphasizes that anticipated guilt partially mediates the association between attitudes, injunctive norms, and descriptive norms on intentions to partake in PEB (Onwezen, Antonides, \& Bartels, 2013; Onwezen et al., 2014b), as well as the relationship between ethical beliefs and ethical intentions (Steenhaut \& Van Kenhove, 2006). 
In addition, anticipated guilt mediates the relationship between opt-out default policy and consumers' intentions to use green services (Theotokis \& Manganari, 2015), sustaining that when green services are offered automatically, consumers refrain from using the unsustainable choice (Theotokis \& Manganari, 2015). In addition to guilt's effect on pro-environmental intentions, it also has a significant impact on behaviors. Research shows that guilt regulates sustainable consumption decisions (Gans \& Groves, 2012), hinders consumers' neutralization efforts (Antonetti \& Maklan, 2014b), and prompts consumers to identify with ethical brands (Newman \& Trump, 2017). In addition, recent research elaborated on consumers' tendency to experience guilt, also known as guilt proneness, over ethical consumption decisions, indicating that consumers who are predisposed to feeling guilty abstain from engaging in unethical behavior (Arli, Leo, \& Tjiptono, 2016).

Notably, the literature highlights the prognostic effect of attitudes, social norms, and high moral identity on guilt (Newman \& Trump, 2017; Onwezen et al., 2014a, 2014b). In addition, Antonetti and Maklan (2014a) emphasized the role of numerous factors that influence social norms such as moral relevance and social visibility of the consumption decision, which in turn has a significant effect on guilt. These effects were prominent in several applications of the theory of planned behavior (Onwezen et al., 2014b; Steenhaut \& Van Kenhove, 2006), the norm activation model (Onwezen et al., 2013), and emotions as feedback systems (Antonetti \& Maklan, 2014a). Furthermore, Chatzidakis (2015) proposed an original perspective of guilt based on Freudian and Kleinian principles, which view guilt as an unconscious emotional state that causes moral behavior.

A significant number of researchers, in the context of PEB, employ anticipatory guilt in their research (Table 2). This can be attributed to ethical considerations when using reactive guilt. As discussed by Antonetti and Baines (2015), utilizing reactive guilt is a way to remind research subjects of previous events where they failed in regulating their behavior. 
Respectively, some events may prove more distressing than others, which may cause research subjects unwarranted grief (Antonetti \& Baines, 2015). Notably, reactive guilt is also examined by researchers (Table 2), yet as recommended by Antonetti and Baines (2015), extreme care should be taken to ensure that the narratives employed do not negatively affect the subjects in any way. For instance, researchers use narratives such as reuse of towels in hotels (Theotokis \& Manganari, 2015), and purchasing Fairtrade, organic, and environmentally friendly products (Antonetti \& Maklan, 2014a, 2014b; Onwezen et al., 2013; Onwezen et al., 2014a, 2014b).

Table 2: Type of guilt, status of guilt as a variable, and observed effect in the context of PEB

\begin{tabular}{|c|c|c|c|}
\hline $\begin{array}{l}\text { Type of } \\
\text { guilt }\end{array}$ & $\begin{array}{l}\text { Guilt as a } \\
\text { variable }\end{array}$ & Observed effect & Source \\
\hline Reactive & Independent & $\begin{array}{l}\text { Guilt from a past behavior prompts consumers to pursue } \\
\text { ethical brands }\end{array}$ & \multirow[t]{3}{*}{$\begin{array}{l}\text { Newman and } \\
\text { Trump (2017) }\end{array}$} \\
\hline Reactive & Independent & $\begin{array}{l}\text { Guilt prompts consumers with high moral identity } \\
\text { importance to associate with ethical brands }\end{array}$ & \\
\hline Reactive & Independent & $\begin{array}{l}\text { Guilt prompts consumers with high moral identity } \\
\text { importance to associate with ethical brands, in particular } \\
\text { when they did not engage in ethical consumption } \\
\text { behavior }\end{array}$ & \\
\hline Anticipatory & Mediator & $\begin{array}{l}\text { Anticipated guilt mediates the association between opt- } \\
\text { out default policy and consumers' intentions to use green } \\
\text { services }\end{array}$ & $\begin{array}{l}\text { Theotokis and } \\
\text { Manganari } \\
\text { (2015) }\end{array}$ \\
\hline Reactive & Independent & $\begin{array}{l}\text { Guilt regulates consumers' sustainable consumption } \\
\text { intentions and decisions } \\
\text { Guilt positively affects consumers' perceived } \\
\text { effectiveness } \\
\text { Guilt negatively influences consumers' neutralization } \\
\text { efforts }\end{array}$ & $\begin{array}{l}\text { Antonetti and } \\
\text { Maklan (2014b) }\end{array}$ \\
\hline \multirow[t]{2}{*}{ Reactive } & Independent & $\begin{array}{l}\text { Guilt is felt in situations where consumers } \\
\text { unintentionally purchase unethical products } \\
\text { Guilt has a significant impact on consumers' future } \\
\text { intentions to buy ethical products }\end{array}$ & \multirow[t]{2}{*}{$\begin{array}{l}\text { Antonetti and } \\
\text { Maklan (2014a) }\end{array}$} \\
\hline & Dependent & Social norms have a significant influence on guilt & \\
\hline \multirow[t]{3}{*}{ Anticipatory } & Mediator & $\begin{array}{l}\text { Anticipated guilt mediates the association between } \\
\text { attitude and social norms on purchase intentions } \\
\text { The mediating effect of anticipated guilt does not differ } \\
\text { within an individualistic or a collectivist culture }\end{array}$ & \multirow[t]{3}{*}{$\begin{array}{l}\text { Onwezen et al. } \\
(2014 a)\end{array}$} \\
\hline & Dependent & $\begin{array}{l}\text { Attitudes have a more significant influence on anticipated } \\
\text { guilt in individualistic cultures as opposed to collectivist } \\
\text { cultures }\end{array}$ & \\
\hline & Independent & $\begin{array}{l}\text { Anticipated guilt affects intentions similarly across } \\
\text { cultures }\end{array}$ & \\
\hline \multirow[t]{2}{*}{ Anticipatory } & Independent & Anticipated guilt has a significant effect on intentions & \multirow{2}{*}{$\begin{array}{l}\text { Onwezen et al. } \\
(2014 b)\end{array}$} \\
\hline & Dependent & $\begin{array}{l}\text { Attitudes, injunctive norms, and descriptive norms } \\
\text { effectively predict guilt }\end{array}$ & \\
\hline
\end{tabular}




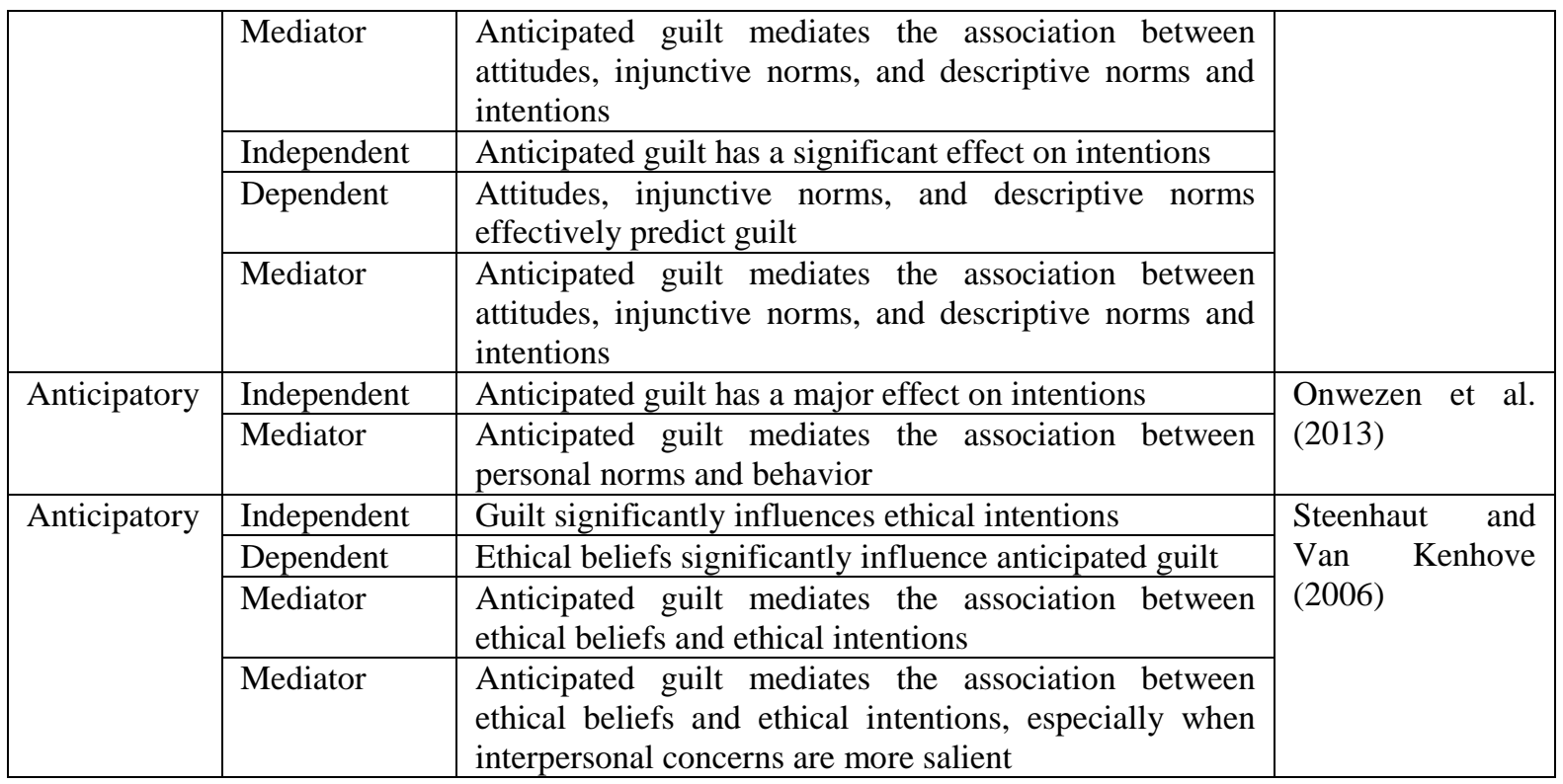

\section{Everyday consumption behavior}

Everyday behavior refers to behavior that incorporates activities that are part of one's daily routine such as cooking meals, going to work, and relaxing (Kleine, Schultzkleine, \& Kernan, 1992). Therefore, everyday consumption transpires as a central part of everyday life-activities (Kleine et al., 1992). Taking that into consideration, a significant number of consumer guilt narratives occur in such circumstances (Han, Duhachek, \& Agrawal, 2014; Soscia, 2007) such as buying food (Dahl et al., 2003; Hur \& Jang, 2015; Onwezen et al., 2014b) going to the gym (Soscia, 2007), and interacting with family, friends, colleagues, and salesmen (Dahl, Honea, \& Manchanda, 2005; Han et al., 2014). Unlike the PEB context, which mostly focuses on assessing the influence of guilt on consumers' intentions and behaviors, the everyday consumption context does not have a clear pattern. This can be the result of the limited research that examines consumer guilt in this context.

Research emphasizes the impact that consumer guilt has on various factors (Table 3). For instance, research showcases that guilt motivates consumers to ruminate on their behavior, and seek emotional support from peers (Saintives \& Lunardo, 2016). Notably, guilt levels increase when peers provide negative feedback, which in turn influences their purchase intentions 
(Saintives \& Lunardo, 2016). Moreover, research highlights the distinctive role guilt has in motivating consumers to purchase self-improvement merchandise. Such influence was not prominent in other negative emotions (Allard \& White, 2015). Further, guilt is found to hinder negative word of mouth and complaining behavior (Soscia, 2007). Sustaining that consumers' social connectedness to a salesperson is mediated by guilt, and it motivates consumers to correct their behavior by making future purchases (Dahl et al., 2005).

Notably, despite consistent results, in the context of PEB that stresses guilt's influence on intentions, this influence was not always present in the context of everyday consumption (Hur \& Jang, 2015). For instance, guilt is found to influence intentions when consumers buy healthy food such as fruit (Onwezen et al., 2014b), yet this influence is absent when they intend to buy quick-service meals (Hur \& Jang, 2015). Such discrepancies are also found between these contexts in terms of guilt's association with attitudes and norms (Dahl et al., 2005; Onwezen et al., 2014b). It is also evident that researchers tend to employ reactive guilt more than anticipated guilt in this context. This can be due to the mild nature of the product categories used in the everyday context, which do not have any ethical implications or pose any psychological threats to the participants (Table 6).

Researchers in the context of everyday consumption utilized a number of theories to achieve the objectives of their research such as cognitive appraisal theory (Allard \& White, 2015; Saintives \& Lunardo, 2016; Soscia, 2007), feed-back theory (Hur \& Jang, 2015), and cognitive dissonance theory (Dahl et al., 2005).

Table 3: Type of guilt, status of guilt as a variable, and observed effect in the context of everyday consumption

\begin{tabular}{|l|l|l|l|}
\hline $\begin{array}{l}\text { Type of } \\
\text { guilt }\end{array}$ & $\begin{array}{l}\text { Guilt as a } \\
\text { variable }\end{array}$ & Observed effect & Source \\
\hline Reactive & Independent & $\begin{array}{l}\text { Guilt positively influences rumination and is positively } \\
\text { associated with emotional support seeking }\end{array}$ & $\begin{array}{l}\text { Saintives and } \\
\text { Lunardo } \\
\text { (2016) }\end{array}$ \\
\cline { 2 - 3 } & Dependent & $\begin{array}{l}\text { When peers give negative feedback on the guilt-inducing } \\
\text { event, guilt is significantly higher in comparison to situations } \\
\text { where the feedback is positive (guilt is low) }\end{array}$ & . \\
\hline
\end{tabular}




\begin{tabular}{|c|c|c|c|}
\hline & Independent & $\begin{array}{l}\text { After negative feedback from peers, high levels of guilt } \\
\text { negatively affect purchase intentions }\end{array}$ & \\
\hline Reactive & Independent & $\begin{array}{l}\text { Guilt motivates consumers' preference for self-improvement } \\
\text { products especially when it's for oneself and not for others } \\
\text { Guilt's influence is more prominent, in terms of preference } \\
\text { for self-improvement products, in comparison to other } \\
\text { negative emotions } \\
\text { This effect was exclusive for individuals who perceive self- } \\
\text { improvement as an attainable consequence }\end{array}$ & $\begin{array}{l}\text { Allard and } \\
\text { White (2015) }\end{array}$ \\
\hline Anticipated & $\begin{array}{l}\text { Dependent } \\
\text { Independent }\end{array}$ & $\begin{array}{l}\text { Perceived healthiness positively influences anticipated guilt } \\
\text { Anticipated guilt does not influence behavioral intentions }\end{array}$ & $\begin{array}{l}\text { Hur and Jang } \\
(2015)\end{array}$ \\
\hline \multirow[t]{2}{*}{ Anticipated } & $\begin{array}{l}\text { Independent } \\
\text { Dependent }\end{array}$ & $\begin{array}{l}\text { Anticipated guilt has a significant effect on intentions } \\
\text { Attitudes and injunctive norms failed to predict anticipated }\end{array}$ & \multirow[t]{2}{*}{$\begin{array}{l}\text { Onwezen et } \\
\text { al. }(2014 b)\end{array}$} \\
\hline & Mediator & $\begin{array}{l}\text { guilt. However, descriptive norms effectively predict guilt } \\
\text { Anticipated guilt does not mediate the association between } \\
\text { attitudes, injunctive norms, and descriptive norms and } \\
\text { intentions }\end{array}$ & \\
\hline \multirow[t]{2}{*}{ Reactive } & Dependent & $\begin{array}{l}\text { Guilt is elicited when goal-incongruent consequences are } \\
\text { caused by the self }\end{array}$ & \multirow[t]{2}{*}{ Soscia (2007) } \\
\hline & Independent & $\begin{array}{l}\text { Guilt prevents negative word of mouth and complaining } \\
\text { behavior }\end{array}$ & \\
\hline \multirow[t]{2}{*}{ Reactive } & Dependent & $\begin{array}{l}\text { Consumers feel more guilt when they do not make a } \\
\text { purchase if they felt a social connection to a salesperson. In } \\
\text { addition, they would pursue reparative behavior to } \\
\text { compensate for their guilt, such as making future purchases }\end{array}$ & \multirow[t]{2}{*}{$\begin{array}{l}\text { Dahl et al. } \\
(2005)\end{array}$} \\
\hline & Mediator & $\begin{array}{l}\text { Guilt mediates the association between social connectedness } \\
\text { to a salesperson and failure to make a purchase }\end{array}$ & \\
\hline
\end{tabular}

\section{Other contexts that examine guilt in consumption}

Existing research examined consumer guilt in contexts such as hedonic and impulsive consumption (Chitturi, Raghunathan, \& Mahajan, 2007; Goldsmith, Cho, \& Dhar, 2012; LeeWingate \& Corfman, 2010; Miao, 2011), and travel and hospitality (Hanks \& Mattila, 2014; Onwezen et al., 2013). In the context of hedonic and impulsive consumption, research indicates that when primed in guilt, individuals feel more pleasure when consuming a particular product, enjoy the consumption experience more, and tend to want to pay more for the product (Goldsmith et al., 2012). These results were consistent in other market offerings that do not affect one's health (Goldsmith et al., 2012). In addition, in the context of travel and hospitality, research examined gender differences with respect to consumer guilt, indicating that women feel more guilt, in particular when they were not in a good mood prior to the purchase (Hanks 
\& Mattila, 2014). Moreover, research reveals that guilt has a negative influence on satisfaction

(Hanks \& Mattila, 2014).

Table 4: Type of guilt, status of guilt as a variable, and observed effect in other contexts

\begin{tabular}{|l|l|l|l|l|}
\hline Context & $\begin{array}{l}\text { Type of } \\
\text { guilt }\end{array}$ & $\begin{array}{l}\text { Guilt as a } \\
\text { variable }\end{array}$ & Observed effect & Source \\
\hline $\begin{array}{l}\text { Hedonic and } \\
\text { impulsive } \\
\text { consumption }\end{array}$ & Reactive & Independent & $\begin{array}{l}\text { When primed in guilt, individuals feel more } \\
\text { pleasure when consuming products }\end{array}$ & $\begin{array}{l}\text { Goldsmith et } \\
\text { al. (2012) }\end{array}$ \\
\cline { 2 - 5 } & Reactive & Dependent & $\begin{array}{l}\text { Guilt is associated with pleasure when } \\
\text { consumers buy on an impulse }\end{array}$ & Miao (2011) \\
\hline $\begin{array}{l}\text { Travel and } \\
\text { hospitality }\end{array}$ & Reactive & Dependent & $\begin{array}{l}\text { Women experience more guilt than men in } \\
\text { a consumption situation where they make } \\
\text { an impulse purchase, especially when they } \\
\text { are in a bad mood }\end{array}$ & $\begin{array}{l}\text { Mattila } \\
\text { (2014) }\end{array}$ \\
\cline { 2 - 3 } & Independent & $\begin{array}{l}\text { Guilt negatively influences anticipated } \\
\text { satisfaction }\end{array}$ & \\
\hline
\end{tabular}

\section{Consumer guilt's narratives}

Due to the intricacy of the cognitive appraisals required to stimulate guilt (Tracy \& Robins, 2004), all researchers who examined consumer guilt in their publications (see Tables $2,3 \& 4$ ) utilized consumption narratives that have the potential to activate those appraisals in the research's subjects. For instance, in the context of PEB, the majority of researchers utilized narratives that incorporate products that were conditioned to be unethical or unsustainable (Antonetti \& Maklan, 2014a, 2014b; Newman \& Trump, 2017; Onwezen et al., 2013; Onwezen et al., 2014a, 2014b; Theotokis \& Manganari, 2015) (Table 5). Limited publications opted for examining consumers' behavior in ethically questionable narratives that do not focus on the product, but rather on other individuals such as salesmen (Steenhaut \& Van Kenhove, 2006).

Table 5: Narratives and product categories employed by researchers in the context of PEB

\begin{tabular}{|l|l|l|}
\hline Narrative & Product & Source \\
\hline $\begin{array}{l}\text { Participants read a description of the chosen brand, } \\
\text { which was adapted from TOMS' mission statement }\end{array}$ & TOMS & Newman and \\
\hline $\begin{array}{l}\text { Participants were asked to mention three things that } \\
\text { they knew or heard about the brand that gives them } \\
\text { the impression that it is an ethical (or unethical) } \\
\text { business }\end{array}$ & Nike & \\
\hline $\begin{array}{l}\text { Subjects were asked to elaborate on an event where } \\
\text { they felt guilty while in the supermarket; then they }\end{array}$ & Wounded Warrior Project & \\
\hline
\end{tabular}




\begin{tabular}{|c|c|c|}
\hline $\begin{array}{l}\text { were asked if they would make a donation to a } \\
\text { charity }\end{array}$ & & \\
\hline $\begin{array}{l}\text { Participants were asked to imagine that they visited } \\
\text { a certain hotel, and towel use policy was explained } \\
\text { to them } \\
\text { Visual stimuli were included in the } \\
\text { appendix of the study }\end{array}$ & Towels & $\begin{array}{l}\text { Theotokis and } \\
\text { Manganari } \\
(2015)\end{array}$ \\
\hline $\begin{array}{l}\text { Subjects were asked to read a scenario about buying } \\
\text { ethical (or unethical) ground coffee } \\
\text { - Visual stimuli were included in the } \\
\text { appendix of the study }\end{array}$ & Ground coffee & $\begin{array}{l}\text { Antonetti and } \\
\text { Maklan (2014b) }\end{array}$ \\
\hline $\begin{array}{l}\text { The participants were given several scenarios such } \\
\text { as buying ethical (or unethical) tea } \\
\text { - Visual stimuli were included in the } \\
\text { appendix of the study }\end{array}$ & Tea & $\begin{array}{l}\text { Antonetti and } \\
\text { Maklan }(2014 a)\end{array}$ \\
\hline $\begin{array}{l}\text { The participants were asked to imagine buying } \\
\text { unethical coffee. And that is the only option they } \\
\text { have }\end{array}$ & Coffee & \\
\hline $\begin{array}{l}\text { The participants filled in a questionnaire that } \\
\text { entailed items related to organic products }\end{array}$ & Organic products & $\begin{array}{l}\text { Onwezen et al. } \\
(2014 \mathrm{a})\end{array}$ \\
\hline $\begin{array}{l}\text { The participants filled in a questionnaire that } \\
\text { entailed items related to environmentally friendly } \\
\text { food and Fairtrade products }\end{array}$ & $\begin{array}{l}\text { Environmentally friendly food such } \\
\text { as sugar, dried fruit, chocolate, } \\
\text { coffee, tea, bananas, and juice }\end{array}$ & $\begin{array}{l}\text { Onwezen et al. } \\
(2014 b)\end{array}$ \\
\hline $\begin{array}{l}\text { The participants filled in a questionnaire that } \\
\text { entailed items related to not buying } \\
\text { environmentally friendly products }\end{array}$ & $\begin{array}{l}\text { Environmentally friendly products } \\
\text { and travel }\end{array}$ & $\begin{array}{l}\text { Onwezen et al. } \\
(2013)\end{array}$ \\
\hline $\begin{array}{l}\text { Participants were asked to imagine a situation } \\
\text { where they receive too much change at a shop } \\
\text { - A script was included in the appendix of } \\
\text { the study }\end{array}$ & $\begin{array}{l}\text { An ethically questionable scenario } \\
\text { was included; the focus was not on } \\
\text { the product but on the salesperson }\end{array}$ & $\begin{array}{l}\text { Steenhaut and } \\
\text { Van Kenhove } \\
(2006)\end{array}$ \\
\hline
\end{tabular}

In the context of everyday consumption, researchers induced guilt by using specific narratives or by asking participants to elaborate on consumption situations that made them feel guilty (Table 6). It is evident that guilt is induced in consumption episodes where the consumer buys expensive products (Saintives \& Lunardo, 2016), consumes unhealthy food or beverages (Allard \& White, 2015; Hur \& Jang, 2015; Onwezen et al., 2013; Saintives \& Lunardo, 2016), does not exercise (Soscia, 2007), and uses products that harm their health (Saintives \& Lunardo, 2016). Similar to the PEB context, researchers in the context of everyday consumption did not focus much on assessing consumer guilt in relation to others. For instance, limited research examined consumer guilt in association with salesmen (Dahl et al., 2005).

Table 6: Narratives and product categories employed by researchers in the context of everyday consumption

\begin{tabular}{|l|l|l|}
\hline Narrative & Product & Source \\
\hline
\end{tabular}




\begin{tabular}{|l|l|l|}
\hline $\begin{array}{l}\text { Participants were required to elaborate on } \\
\text { consumption situations where they felt guilty }\end{array}$ & $\begin{array}{l}\text { The most cited consumption situations } \\
\text { were buying expensive clothes, drinking } \\
\text { alcohol, eating unhealthy food, taking } \\
\text { drugs, smoking cigarettes }\end{array}$ & $\begin{array}{l}\text { Saintives and } \\
\text { Lunardo } \\
(2016)\end{array}$ \\
\hline $\begin{array}{l}\text { Respondents were shown a poster that urged them } \\
\text { to donate blood }\end{array}$ & $\begin{array}{l}\text { Self-improvement products (vitamin } \\
\text { water, sticky notes, tea) }\end{array}$ & $\begin{array}{l}\text { Allard and } \\
\text { White (2015) }\end{array}$ \\
\hline $\begin{array}{l}\text { A hypothetical advertisement was shown to the } \\
\text { participants figure illustrating the advertisement } \\
\text { was shown in the study }\end{array}$ & $\begin{array}{l}\text { Quick service meals } \\
\text { (2015) }\end{array}$ \\
$\begin{array}{l}\text { Respondents were asked to report the amount in } \\
\text { which they ate specific categories of fruit } \\
\text { A script was included in the study }\end{array}$ & $\begin{array}{l}\text { Fruits such as citrus fruit, tangerines, } \\
\text { strawberries, and apples }\end{array}$ & $\begin{array}{l}\text { Onwezen et } \\
\text { al. (2014b) }\end{array}$ \\
\hline $\begin{array}{l}\text { Participants were given brief narratives that entail } \\
\text { consumption experiences of numerous } \\
\text { consumers }\end{array}$ & Fitness center & Soscia (2007) \\
$\begin{array}{l}\text { Subjects were told to partake in a shopping } \\
\text { experience at two different retailers, and then they } \\
\text { were required to give feedback on their shopping } \\
\text { experience }\end{array}$ & $\begin{array}{l}\text { The focus was not on the product but on } \\
\text { the salesperson }\end{array}$ & $\begin{array}{l}\text { Dahl et al. } \\
\text { (2005) }\end{array}$ \\
\hline $\begin{array}{l}\text { Subjects read a narrative where they had to interact } \\
\text { with a salesperson }\end{array}$ & & \\
\hline
\end{tabular}

Note 2: Page numbers are included in sources that incorporate a visual stimulus or scripts

In other consumption contexts, researchers utilized food that is perceived as unhealthy to induce consumer guilt in participants (Goldsmith et al., 2012; Miao, 2011) (Table 7). Further, in the travel and hospitality context, researchers used impulsive purchases of expensive trips to generate guilt in participants (Hanks \& Mattila, 2014). Respectively, the majority of publications in all contexts focused on food items that are perceived as unhealthy or harmful to one's health. A limited number of publications examined narratives that had interpersonal focus (Hanks \& Mattila, 2014; Steenhaut \& Van Kenhove, 2006), or used the web as a platform for the guilt-inducing narrative (Goldsmith et al., 2012).

Table 7: Narratives and product categories employed by researchers in the other contexts

\begin{tabular}{|c|c|c|}
\hline Narrative & Product & Source \\
\hline Participants were asked to taste chocolate candy. & Candy & $\begin{array}{l}\text { Goldsmith et } \\
\text { al. (2012) }\end{array}$ \\
\hline $\begin{array}{l}\text { Female participants were required to imagine that they wanted } \\
\text { to use online dating websites to find romance, and they had to } \\
\text { view five profiles of local men }\end{array}$ & Online dating & \\
\hline $\begin{array}{l}\text { Participants read a script that entails a scenario of a woman } \\
\text { wanting to buy cheesecake }\end{array}$ & Cheesecake & Miao (2011) \\
\hline
\end{tabular}




\begin{tabular}{|l|l|l|}
\hline \multicolumn{1}{|c|}{ A script was included in the study } & & \\
\hline $\begin{array}{l}\text { Participants read a script that involves a hypothetical scenario } \\
\text { where they bought a three-day cruise. }\end{array}$ & $\begin{array}{l}\text { Impulsive purchase of a } \\
\text { three-day cruise priced at } \\
500 \$\end{array}$ & $\begin{array}{l}\text { Hanks and } \\
\text { Mattila (2014) }\end{array}$ \\
\hline
\end{tabular}

Note 3: Page numbers are included in sources that incorporate a visual stimulus or scripts

\section{Research methodology}

Researchers who want to examine guilt in consumer behavior can make informed decisions as to which research method is best suited to achieve their objectives. Therefore, evaluating the approach of previous researchers in the field may present practical guidance and potential methodological contributions. Accordingly, this section inspects the research methods, sampling, analytical techniques, and measurement scales of existing research.

With respect to the methodology in the context of PEB, the majority of research employed quantitative research methods and experimental designs (Table 8). In addition, a significant number of publications used a representative sample and mostly avoided using a student sample. However, the majority of these publications recruited participants from the United States and other individualistic countries such as the Netherlands, Canada, and Australia. Moreover, various modern analytical techniques were used such as structural equation modeling (SEM) (Steenhaut \& Van Kenhove, 2006), partial least squares path modeling (PLS) method to SEM (Antonetti \& Maklan, 2014a, 2014b), and Mediated Moderation (Theotokis \& Manganari, 2015). In terms of the scales used in this context, numerous scales were used to measure guilt (Table 8). Notably, each researcher preferred the use of a specific scale. For example, a scale adapted from (Roseman, 1991; Soscia, 2007) was used by (Antonetti \& Maklan, 2014a, 2014b), whereas a scale adapted from (Holbrook \& Batra, 1987) was mostly used by (Onwezen et al., 2014a, 2014b). The Cronbach's alpha of all scales surpassed the accepted benchmark of 0.70 (Table 8$)$.

Table 8: Aspects of research methodology in the context of PEB

\begin{tabular}{|l|l|l|l|l|}
\hline Study & Sample & Methodology & Scale & $\begin{array}{l}\text { Scale's } \\
\text { Alpha }\end{array}$ \\
\hline
\end{tabular}




\begin{tabular}{|c|c|c|c|c|}
\hline $\begin{array}{l}\text { Newman and } \\
\text { Trump } \\
(2017)\end{array}$ & $\begin{array}{l}127 \text { respondents were recruited } \\
\text { through Amazon Mechanical Turk } \\
\text { (AMT) in study-1 } \\
73 \text { respondents were recruited } \\
\text { through AMT in study-2 } \\
260 \text { respondents were recruited } \\
\text { through AMT in study-3 } \\
\text { *pre-tests were applied using } \\
\text { American brands. Thus, it can be } \\
\text { assumed that the sample comprises } \\
\text { American subjects }\end{array}$ & $\begin{array}{l}\text { Quantitative } \\
\text { online experiment } \\
\text { t-tests, regression, } \\
\text { and Johnson-- } \\
\text { Neyman techniques } \\
\text { were used for } \\
\text { analysis }\end{array}$ & $\begin{array}{l}\text { A three-item scale } \\
\text { adapted from } \\
\text { (Zemack-Rugar, } \\
\text { Bettman, \& } \\
\text { Fitzsimons, 2007) } \\
\text { A one-item scale } \\
\text { adapted from } \\
\text { (Allard \& White, } \\
\text { 2015) }\end{array}$ & 0.94 \\
\hline $\begin{array}{l}\text { Theotokis } \\
\text { and } \\
\text { Manganari } \\
(2015)\end{array}$ & 112 postgraduate students & $\begin{array}{l}\text { Quantitative } \\
\text { experiment } \\
\text { Mediated } \\
\text { moderation was used } \\
\text { for analysis }\end{array}$ & $\begin{array}{l}\text { A four-item scale } \\
\text { adapted from } \\
\text { (Dahl et al., 2005) }\end{array}$ & $\mathrm{N} / \mathrm{S}$ \\
\hline $\begin{array}{l}\text { Antonetti } \\
\text { and Maklan } \\
(2014 b)\end{array}$ & $\begin{array}{l}415 \text { American citizens were } \\
\text { recruited through AMT in study-1 } \\
135 \text { American citizens were } \\
\text { recruited and interviewed through } \\
\text { AMT }\end{array}$ & $\begin{array}{l}\text { Quantitative } \\
\text { online experiment in } \\
\text { study-1 } \\
\text { Online surveys in } \\
\text { study-2 } \\
\text { PLS-SEM was used } \\
\text { for analysis }\end{array}$ & $\begin{array}{l}\text { Three-item scale } \\
\text { adapted from } \\
\text { (Roseman, 1991; } \\
\text { Soscia, 2007) }\end{array}$ & 0.96 \\
\hline $\begin{array}{l}\text { Antonetti } \\
\text { and Maklan } \\
(2014 a)\end{array}$ & $\begin{array}{l}181 \text { American citizens participated } \\
\text { in study-1 } \\
279 \text { American citizens were } \\
\text { recruited through AMT in study-2 } \\
30 \text { participants took part in study-3 }\end{array}$ & $\begin{array}{l}\text { Quantitative } \\
\text { online experiment in } \\
\text { studies-1 \& } 2 \\
\text { PLS-SEM was used } \\
\text { for analysis } \\
\text { Qualitative in-depth } \\
\text { interviews in study-3 } \\
\text { NVivo was used for } \\
\text { analysis }\end{array}$ & $\begin{array}{l}\text { Three-item scale } \\
\text { adapted from } \\
\text { (Roseman, 1991; } \\
\text { Soscia, 2007) }\end{array}$ & 0.83 \\
\hline $\begin{array}{l}\text { Onwezen et } \\
\text { al. }(2014 a)\end{array}$ & $\begin{array}{l}3854 \text { individuals were recruited } \\
\text { through a research agency from } \\
\text { Canada (510), Australia (507), } \\
\text { Germany (514), the Netherlands } \\
\text { (507), the United Kingdom (503), } \\
\text { the United States (507), Malaysia } \\
\text { (403), and Singapore (403) }\end{array}$ & $\begin{array}{l}\text { Quantitative } \\
\text { online survey } \\
\text { Structural regression } \\
\text { models conducted } \\
\text { via Mplus }\end{array}$ & $\begin{array}{l}\text { Three-item scale } \\
\text { adapted from } \\
\text { (Holbrook \& } \\
\text { Batra, 1987) }\end{array}$ & 0.96 \\
\hline $\begin{array}{l}\text { Onwezen et } \\
\text { al. }(2014 b)\end{array}$ & $\begin{array}{l}944 \text { Dutch citizens recruited via an } \\
\text { online agency in study-1 } \\
1845 \text { Dutch citizens recruited via an } \\
\text { online agency in study-2 }\end{array}$ & $\begin{array}{l}\text { Quantitative } \\
\text { online survey } \\
\text { Latent models } \\
\text { conducted via Mplus } \\
\text { were used for } \\
\text { analysis }\end{array}$ & $\begin{array}{l}\text { One item selected } \\
\text { from (Holbrook \& } \\
\text { Batra, 1987) } \\
\text { Three items } \\
\text { adapted from } \\
\text { (Holbrook \& } \\
\text { Batra, 1987) }\end{array}$ & 0.98 \\
\hline $\begin{array}{l}\text { Onwezen et } \\
\text { al. }(2013)\end{array}$ & $\begin{array}{l}617 \text { Dutch citizens recruited via an } \\
\text { online agency }\end{array}$ & $\begin{array}{l}\text { Quantitative } \\
\text { online survey }\end{array}$ & $\begin{array}{l}\text { Five-item scale } \\
\text { adapted from }\end{array}$ & 0.97 \\
\hline
\end{tabular}




\begin{tabular}{|c|c|c|c|c|}
\hline & & $\begin{array}{l}\text { Structural regression } \\
\text { models }\end{array}$ & $\begin{array}{l}\text { (Kugler \& Jones, } \\
\text { 1992) }\end{array}$ & \\
\hline $\begin{array}{l}\text { Steenhaut } \\
\text { and Van } \\
\text { Kenhove } \\
(2006)\end{array}$ & $\begin{array}{l}120 \text { subjects were intercepted in a } \\
\text { random walk method in study-1 } \\
78 \text { bachelor students in study- } 2\end{array}$ & 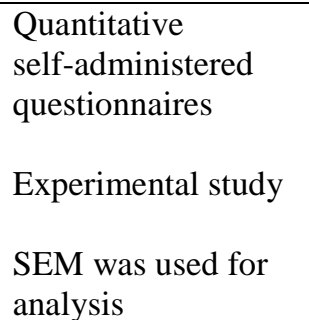 & $\begin{array}{l}10 \text { items adapted } \\
\text { from (Roseman, } \\
\text { Wiest, \& Swartz, } \\
\text { 1994) }\end{array}$ & 0.91 \\
\hline
\end{tabular}

Note 4: N/S = not specified

In terms of the methodology used in the context of everyday consumption, researchers mostly employed quantitative research methods (Table 9). Notably, dissimilar to the context of PEB, researchers in the context of everyday consumption mostly used a student sample. Moreover, in accordance with the context of PEB (Table 9), the majority of the research was conducted in individualistic cultures (Table 9). Regarding the analysis techniques used in this context, a limited number of publications used advanced analysis techniques such as SEM, and opted for traditional techniques such as regression and ANOVA. In addition, similar to the PEB context, no specific pattern emerged with respect to the measurement scales used in the context of everyday consumption. The reported Cronbach's alphas of these scales were acceptable.

Table 9: Aspects of research methodology in the context of everyday consumption

\begin{tabular}{|c|c|c|c|c|}
\hline Study & Sample & Methodology & Scale & $\begin{array}{l}\text { Scale's } \\
\text { Alpha }\end{array}$ \\
\hline $\begin{array}{l}\text { Saintives } \\
\text { and Lunardo } \\
(2016)\end{array}$ & $\begin{array}{l}95 \text { French students } \\
\text { participated in } \\
\text { study-1 } \\
154 \text { participants in } \\
\text { study-2 }\end{array}$ & $\begin{array}{l}\text { Quantitative } \\
\text { self-administered } \\
\text { questionnaires } \\
\text { Experimental design } \\
\text { Multiple linear regression, } \\
\text { t-test, and ANOVA were } \\
\text { used for analysis }\end{array}$ & $\begin{array}{l}\text { Three items found in the } \\
\text { literature of (Dahl et al., 2005) }\end{array}$ & $\begin{array}{l}0.71 \\
0.84\end{array}$ \\
\hline $\begin{array}{l}\text { Allard and } \\
\text { White } \\
(2015)\end{array}$ & $\begin{array}{l}169 \text { participants } \\
\text { were recruited } \\
\text { through AMT in } \\
\text { study-1 } \\
166 \text { students } \\
\text { participated in } \\
\text { study-2 } \\
157 \text { students took } \\
\text { part in study-3 }\end{array}$ & $\begin{array}{l}\text { Quantitative } \\
\text { experimental design } \\
\text { ANOVA and regression } \\
\text { analysis }\end{array}$ & $\begin{array}{l}\text { Written description and a } \\
\text { three-item scale as } \\
\text { recommended by } \\
\text { (Tangney et al., 1996) }\end{array}$ & 0.96 \\
\hline
\end{tabular}




\begin{tabular}{|c|c|c|c|c|}
\hline & $\begin{array}{l}244 \text { participants } \\
\text { took part in study- } 4 \\
390 \text { participants } \\
\text { were recruited } \\
\text { through AMT in } \\
\text { study-5 }\end{array}$ & & & \\
\hline $\begin{array}{l}\text { Hur and } \\
\text { Jang (2015) }\end{array}$ & $\begin{array}{l}809 \text { American } \\
\text { consumers }\end{array}$ & $\begin{array}{l}\text { Quantitative } \\
\text { online survey } \\
\text { SEM was used for } \\
\text { analysis }\end{array}$ & $\begin{array}{l}\text { Three-item scale adapted from } \\
\text { (Burnett \& Lunsford, 1994; } \\
\text { Roseman et al., 1994) }\end{array}$ & 0.95 \\
\hline $\begin{array}{l}\text { Onwezen et } \\
\text { al. }(2014 b)\end{array}$ & $\begin{array}{l}491 \text { Dutch } \\
\text { consumers } \\
\text { recruited through } \\
\text { an online agency }\end{array}$ & $\begin{array}{l}\text { Quantitative } \\
\text { online survey } \\
\text { Latent models conducted } \\
\text { via Mplus were used for } \\
\text { analysis }\end{array}$ & $\begin{array}{l}\text { Three items adapted from } \\
\text { (Holbrook \& Batra, 1987) }\end{array}$ & 0.98 \\
\hline $\begin{array}{l}\text { Soscia } \\
(2007)\end{array}$ & 182 Italian students & $\begin{array}{l}\text { Quantitative } \\
\text { experimental design } \\
\text { ANOVA, factor analysis, } \\
\text { MANOVA, and multiple } \\
\text { regression were used for } \\
\text { analysis }\end{array}$ & $\begin{array}{l}\text { Two-item scale } \\
\text { Source not disclosed }\end{array}$ & $\mathrm{N} / \mathrm{S}$ \\
\hline $\begin{array}{l}\text { Dahl et al. } \\
(2005)\end{array}$ & $\begin{array}{l}105 \text { students in } \\
\text { study-1 } \\
103 \text { students in } \\
\text { study-2 }\end{array}$ & $\begin{array}{l}\text { Quantitative } \\
\text { experimental design } \\
\text { Factor analysis }\end{array}$ & $\begin{array}{l}\text { Three-item scale devised from } \\
\text { previous research (Coulter \& } \\
\text { Pinto, 1995; Jones, Schratter, } \\
\& \text { Kugler, 2000) }\end{array}$ & $\mathrm{N} / \mathrm{S}$ \\
\hline
\end{tabular}

Note $5: N / S=$ not specified

With respect to the other contexts, the limited research available did not significantly differ from the everyday consumption context. Researchers mostly used quantitative methods, participants from individualistic countries, and traditional analysis techniques (Table 10).

Table 10: Aspects of research methodology in other contexts

\begin{tabular}{|l|l|l|l|l|l|}
\hline Context & Study & Sample & Methodology & Scale & $\begin{array}{l}\text { Scale's } \\
\text { Alpha }\end{array}$ \\
\hline $\begin{array}{l}\text { Hedonic and } \\
\text { impulse } \\
\text { consumption }\end{array}$ & $\begin{array}{l}\text { Goldsmith et } \\
\text { al. (2012) }\end{array}$ & $\begin{array}{l}100 \text { participated in } \\
\text { study-1 } \\
40 \text { females } \\
\text { participated in study-2 } \\
108 \text { students in study- } \\
3\end{array}$ & $\begin{array}{l}\text { Quantitative } \\
\text { experimental design }\end{array}$ & $\begin{array}{l}\text { (Fischhoff, } \\
\text { Gonzalez, } \\
\text { Small, \& } \\
\text { Lerner, 2003) }\end{array}$ & N/S \\
& & & & \\
& & & & \\
& & & & \\
& Miao participants & 278 American \\
participants & $\begin{array}{l}\text { Quantitative } \\
\text { experimental design }\end{array}$ & N/S & N/S \\
\hline
\end{tabular}




\begin{tabular}{|l|l|l|l|l|l|}
\hline & & & $\begin{array}{l}\text { Hierarchical } \\
\text { multiple regression, } \\
\text { ANOVA was used } \\
\text { for analysis }\end{array}$ & & \\
\hline $\begin{array}{l}\text { Travel and } \\
\text { hospitality }\end{array}$ & $\begin{array}{l}\text { Hanks and } \\
\text { Mattila (2014) }\end{array}$ & $\begin{array}{l}\text { 20 American } \\
\text { participants took part } \\
\text { in the focus group } \\
\text { Qualitative } \\
\text { focus group } \\
\text { 384 American } \\
\text { participants took part } \\
\text { in the quantitative } \\
\text { study; they were } \\
\text { recruited through } \\
\text { AMT }\end{array}$ & $\begin{array}{l}\text { Three-item scale } \\
\text { experimental design } \\
\text { adapted from } \\
\text { (Kugler \& } \\
\text { Jones, 1992) } \\
\text { hierarchical } \\
\text { regression were } \\
\text { used for analysis }\end{array}$ & N/S & \\
\hline
\end{tabular}

Note 6: $N / S=$ not specified

\section{Discussion}

Guilt is a complex emotion that requires researchers to be mindful of a number of complicated issues related to its elicitation in order to make informed decisions. As mentioned earlier, this review argues that the nature of guilt-induced behavior relies on three specific elements (Figure 1): agency or cause of guilt (self, society, others/action, inaction); form or manifestation of guilt (anticipatory, reactive, and existential); and moderating factors (culture, demographics, narrative). In view of that, the previous sections highlight a lack of diversity, and contextual inconsistencies, with regard to these factors. First, when inspecting the form of guilt, the majority of research utilized reactive guilt (Allard \& White, 2015; Antonetti \& Maklan, 2014a, 2014b; Dahl et al., 2005; Goldsmith et al., 2012; Hanks \& Mattila, 2014; Miao, 2011; Newman \& Trump, 2017; Saintives \& Lunardo, 2016; Soscia, 2007) followed by anticipatory guilt (Onwezen et al., 2013; Onwezen et al., 2014a, 2014b; Steenhaut \& Van Kenhove, 2006; Theotokis \& Manganari, 2015) while no research has examined existential guilt.

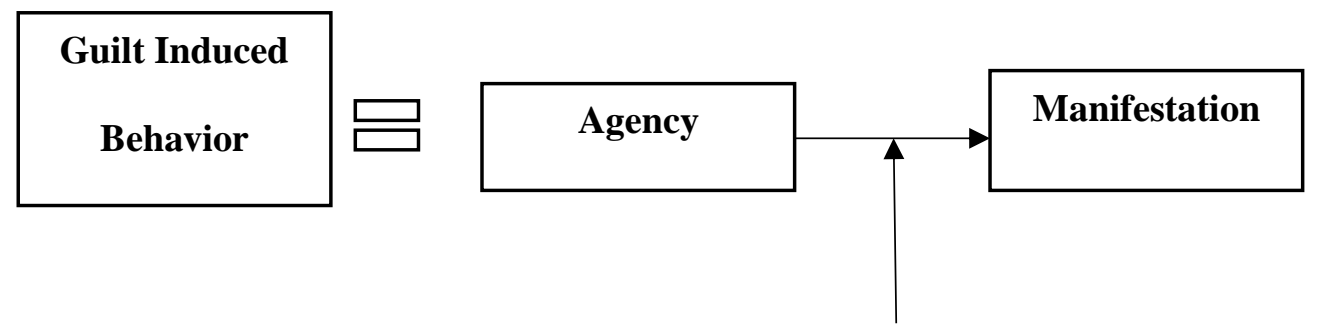


Second, in terms of the cause of guilt, the majority of research, in the examined contexts, evaluated guilt that is related to the self (caused by one's actions) (Allard \& White, 2015; Newman \& Trump, 2017) followed by guilt that is related to societal standards (Theotokis \& Manganari, 2015). Limited research examined guilt that is related to others and guilt as result one's inactions (Dahl et al., 2005; Steenhaut \& Van Kenhove, 2006). Third, with respect to moderating factors, most narratives used food items, in various settings, to induce guilt (Allard \& White, 2015; Antonetti \& Maklan, 2014a, 2014b; Goldsmith et al., 2012; Hur \& Jang, 2015; Miao, 2011; Onwezen et al., 2014a, 2014b; Saintives \& Lunardo, 2016), and utilized samples from individualistic cultures (Tables $8,9, \& 10$ ). Overall, this lack of diversity and contextual inconsistencies might affect the applicability of the results. For instance, taking a moderating factor, such as participants' gender in the context of everyday consumption (Table 11), reveals that not all studies had comparable percentages of females and males. Moreover, these studies were conducted in individualistic cultures where gender differences are significant and women experience more guilt than men (Kayal et al., 2017). Therefore, results generated from studies that had incomparable percentages of males and females should be approached with caution as the increased number of females may influence the level of guilt.

Table 11: Participants' gender in the context of everyday consumption

\begin{tabular}{|l|l|l|}
\hline Study & Sample & Gender percentage \\
\hline $\begin{array}{l}\text { Saintives and Lunardo } \\
(2016)\end{array}$ & $\begin{array}{l}\text { 95 French students participated in } \\
\text { study-1 }\end{array}$ & $\begin{array}{l}\text { Females }=51 \% \\
\text { Males }=49 \%\end{array}$ \\
& 154 participants in study-2 \\
& & $\begin{array}{l}\text { Females }=61 \% \\
\text { Males }=39 \%\end{array}$ \\
\hline
\end{tabular}




\begin{tabular}{|c|c|c|}
\hline Allard and White (2015) & $\begin{array}{l}169 \text { participants were recruited } \\
\text { through AMT in study-1 } \\
166 \text { students participated in study-2 } \\
157 \text { students took part in study-3 } \\
244 \text { participants took part in study-4 } \\
390 \text { participants were recruited } \\
\text { through AMT in study-5 }\end{array}$ & $\begin{array}{l}\text { Females }=50 \% \\
\text { Males }=50 \% \\
\text { Females }=60 \% \\
\text { Males }=40 \% \\
\text { Females }=53 \% \\
\text { Males }=47 \% \\
\text { Females }=65 \% \\
\text { Males }=35 \% \\
\text { Females }=45 \% \\
\text { Males }=55 \%\end{array}$ \\
\hline Hur and Jang (2015) & 809 American consumers & $\begin{array}{l}\text { Females }=50.2 \% \\
\text { Males }=49.8 \%\end{array}$ \\
\hline Onwezen et al. (2014b) & $\begin{array}{l}491 \text { Dutch consumers recruited } \\
\text { through an online agency }\end{array}$ & $\begin{array}{l}\text { Females }=50.2 \% \\
\text { Males }=49.8 \%\end{array}$ \\
\hline Soscia (2007) & 182 Italian students & $\begin{array}{l}\text { Females }=100 \% \\
\text { Males }=0 \%\end{array}$ \\
\hline Dahl et al. (2005) & $\begin{array}{l}105 \text { students in study-1 } \\
103 \text { students in study-2 }\end{array}$ & $\begin{array}{l}\text { Not Specified } \\
\text { Females }=56 \% \\
\text { Males }=44 \%\end{array}$ \\
\hline
\end{tabular}

\section{Guidance for future researchers}

Taking that into consideration, and using Figure 1 as a foundation for examining consumer guilt, researchers have to decide which form of guilt they are going to employ. As previously discussed, ethical considerations restrain researchers from inducing reactive guilt, especially in sensitive consumption narratives (Antonetti \& Baines, 2015). Therefore, by following in the footsteps of previous researchers, special care has to be taken while employing reactive guilt. Of note, there is yet to be research that examines existential guilt in consumption; thus, future researchers might want to consider this type of guilt, as it presents them with opportunities to contribute to knowledge in that area. Moreover, with respect to the cause of guilt, future researchers would make a significant contribution by examining consumer guilt that is related to others (Table 12). Furthermore, the majority of research examined consumer guilt as a result of consumers' actions; hence, future researchers should assess guilt as a result of consumers' inactions (Table 12). 
In terms of moderating factors, the review revealed that the majority of consumer guilt research was conducted using American participants, and participants from other individualistic cultures (Tables 8, 9, \& 10). Existing research emphasizes that experiences of guilt do differ as a result of cultural variations (Onwezen et al., 2014a); consequently, future researchers may attempt to employ their research in collectivist cultures in order to identify mutual patterns and discrepancies among and within cultures. Moreover, researchers have to be mindful of selecting equal percentages of men and women in their sample, as women tend to experience more guilt than men in consumption circumstances (Hanks \& Mattila, 2014; Kayal et al., 2017). Thus, unequal number of men and women might distort the results and generate false conclusions, in particular in individualistic countries (Kayal et al., 2017). Further, researchers have to consider the age of the participants, as levels of guilt significantly differ with age (Orth, Robins, \& Soto, 2010).

It is vital to consider other moderating factors, such as product type, as the majority of existing research utilized food items to elicit guilt. It can be argued that food items are not highly relevant to the majority of consumers (Ratchford, 1987), which can explain the average and below-average levels of guilt induced in these studies (Allard \& White, 2015; Antonetti \& Maklan, 2014a, 2014b; Goldsmith et al., 2012). With respect to methodology-related decisions, such as research methods, sampling, measurement scales, and analysis, have to be carefully considered. With respect to research methods, the majority of consumer guilt research utilized quantitative research methods (Tables $8,9, \& 10$ ). Therefore, future researchers might want to employ qualitative research methods to identify other product categories that induce guilt, thus incorporating them in guilt-inducing narratives in quantitative research.

Table 12: Unexplored narratives that induce consumer guilt

\begin{tabular}{|l|l|}
\hline Narrative & Category of guilt \\
\hline Disposing of recyclable goods incorrectly & $\begin{array}{l}\text { Guilt related to societal standards and } \\
\text { consumers' actions }\end{array}$ \\
\cline { 1 - 2 } $\begin{array}{l}\text { Using non-reusable items or damaging the environment } \\
\text { indirectly }\end{array}$ & \\
\hline
\end{tabular}




\begin{tabular}{|c|c|}
\hline Buying foreign products instead of local ones & \\
\hline Not giving money to charity, or needy people & \multirow{2}{*}{$\begin{array}{l}\text { Guilt related to societal standards and } \\
\text { consumers' inactions }\end{array}$} \\
\hline $\begin{array}{l}\text { Not buying products from needy children or causes that benefit } \\
\text { the society }\end{array}$ & \\
\hline $\begin{array}{l}\text { Frivolous purchases of expensive items such as clothing, } \\
\text { jewellery, beauty products, and entertainment }\end{array}$ & \multirow[t]{2}{*}{$\begin{array}{l}\text { Guilt related to the self and consumers' } \\
\text { actions }\end{array}$} \\
\hline $\begin{array}{l}\text { Buying products that can harm one's health (cigarettes, alcohol, } \\
\text { drugs) }\end{array}$ & \\
\hline $\begin{array}{l}\text { Not considering available product information before purchase } \\
\text { (reserving a hotel without checking its ratings or reviews) }\end{array}$ & \multirow{2}{*}{$\begin{array}{l}\text { Guilt related to the self and consumers' } \\
\text { inactions }\end{array}$} \\
\hline $\begin{array}{l}\text { Not using products already bought (gym membership, rented } \\
\text { movies) }\end{array}$ & \\
\hline Disposing of children's possessions & \multirow{5}{*}{$\begin{array}{l}\text { Guilt related to others and consumers' } \\
\text { actions }\end{array}$} \\
\hline Buying convenience food for one's children & \\
\hline $\begin{array}{l}\text { Spending family money without consulting a spouse or } \\
\text { spending family savings }\end{array}$ & \\
\hline $\begin{array}{l}\text { Buying products that in turn can negatively impact others (child } \\
\text { labour) }\end{array}$ & \\
\hline Buying from brands that experiment on animals & \\
\hline Buying expensive items while others suffer from poverty & $\begin{array}{l}\text { Guilt related to others and consumers' } \\
\text { actions with an emphasis on existential guilt }\end{array}$ \\
\hline Not using products given by close individuals & \multirow{3}{*}{$\begin{array}{l}\text { Guilt related to others and consumers' } \\
\text { inactions }\end{array}$} \\
\hline Not buying from a salesperson who spends time and effort & \\
\hline Not tipping for great services & \\
\hline
\end{tabular}

In addition, as evident from the review, researchers utilized established theories and frameworks (e.g., theory of planned behavior, and cognitive appraisal theory) to examine factors that are either affected or influenced by guilt. Yet, the complexity of the appraisals leading to guilt, as well as an absence of a theoretical framework dedicated to consumer guilt, resulted in a tendency to examine limited factors such as social norms, intentions, behavior, and a few appraisals of guilt. For instance, scholars examined self-accountability (Peloza, White, \& Shang, 2013), local attributions (Han et al., 2014), goal-incongruence (Soscia, 2007), and attitudes and social norms (Onwezen et al., 2013; Onwezen et al., 2014a, 2014b). Yet, there is still a need to examine other appraisals and factors such as goal relevance (Nyer, 1997), guilt proneness (Arli et al., 2016; Cohen et al., 2012; Han et al., 2014), and guilt repair (Arli et al., 2016; Cohen, Wolf, Panter, \& Insko, 2011). 
Identifying a novel extension of consumer guilt: E-guilt

Despite the popularity of examining consumer behavior in online settings (Koufaris, 2002), consumer guilt in such settings is yet to be evaluated. As the present review already established, different consumption settings significantly influence consumer guilt. Goldsmith et al. (2012) used a narrative that incorporates online consumption as a platform for consumer guilt (Table 7). The rationale behind the significance of such a setting is that feelings of guilt tend to fluctuate in association with the visibility of the behavior to others (Antonetti \& Maklan, 2014a). Therefore, the web represents unconventional circumstances where one's actions can be easily visible and irreversible to others. For instance, studies indicate that individuals feel guilt when posting online reviews or comments (Bradley, Sparks, \& Weber, 2015), and spending too much time online (Caplan, 2003). In addition, due to the ease and popularity of e-commerce, studies show that guilt is felt in the aftermath of impulsive purchases online (Bennett, 2009). In view of the literature, e-guilt would be similar to consumer guilt in terms of its elicitation process, characteristics, and influence; however, it would differ in its experience and severity as it manifests itself in visible and irreversible circumstances.

\section{Concluding remarks}

A comprehensive examination of literature of guilt in consumption emphasizes the need to take into consideration numerous factors when assessing guilt. Respectively, researchers need to make decisions with respect to the form, cause, and moderating factors that induce guilt in consumption. The complexity of guilt dictates that, without careful consideration of these factors, holistic knowledge cannot be achieved. This was evident as the majority of research that evaluates consumer guilt employed similar forms, induced by similar causes, with monotonous moderating factors. Therefore, the bulk of research dedicated to consumer guilt cannot be all-inclusive, as it does not take into consideration other forms, causes, and factors influencing guilt-induced behavior. In view of that, this review is an attempt to clarify the 
importance of assessing the factors included in Figure 1 (i.e., the cause, form, moderating factors), as failure to do so hinders the comprehensiveness and, to a certain extent, the reliability and validity of findings.

\section{References}

Ajzen, I. (1991). The theory of planned behavior. Organizational behavior and human decision processes, 50(2), 179-211.

Allard, T., \& White, K. (2015). Cross-domain effects of guilt on desire for self-improvement products. Journal of Consumer Research, 42(3), 401-419.

Antonetti, P., \& Baines, P. (2015). Guilt in marketing research: An elicitation-consumption perspective and research agenda. International Journal of Management Reviews, 17(3), 333-355.

Antonetti, P., Baines, P., \& Walker, L. (2015). From elicitation to consumption: assessing the longitudinal effectiveness of negative emotional appeals in social marketing. Journal of Marketing Management, 31(9-10), 940-969.

Antonetti, P., \& Maklan, S. (2014a). Exploring postconsumption guilt and pride in the context of sustainability. Psychology \& Marketing, 31(9), 717-735.

Antonetti, P., \& Maklan, S. (2014b). Feelings that make a difference: How guilt and pride convince consumers of the effectiveness of sustainable consumption choices. Journal of Business Ethics, 124(1), 117-134.

Arli, D., Leo, C., \& Tjiptono, F. (2016). Investigating the impact of guilt and shame proneness on consumer ethics: A cross national study. International Journal of Consumer Studies, 40(1), 2-13.

Baumeister, R. F., Stillwell, A. M., \& Heatherton, T. F. (1994). Guilt - an interpersonal approach. Psychological Bulletin, 115(2), 243-267.

Bennett, R. (2009). Impulsive donation decisions during online browsing of charity websites. Journal of Consumer Behaviour, 8(2-3), 116-134.

Bradley, G. L., Sparks, B. A., \& Weber, K. (2015). The stress of anonymous online reviews: a conceptual model and research agenda. International Journal of Contemporary Hospitality Management, 27(5), 739-755.

Burnett, M., \& Lunsford, D. (1994). Conceptualizing guilt in the consumer decision-making process. Journal of Consumer Marketing, 11(3), 33-43

Caplan, S. E. (2003). Preference for online social interaction: A theory of problematic Internet use and psychosocial well-being. Communication Research, 30(6), 625-648. 
Chatzidakis, A. (2015). Guilt and ethical choice in consumption: A psychoanalytic perspective. Marketing Theory, 15(1), 79-93.

Chitturi, R., Raghunathan, R., \& Mahajan, V. (2007). Form versus function: How the intensities of specific emotions evoked in functional versus hedonic trade-offs mediate product preferences. Journal of Marketing Research, 44(4), 702-714.

Cohen, Panter, \& Turan. (2012). Guilt proneness and moral character. Current Directions in Psychological Science, 21(5), 355-359.

Cohen, Panter, \& Turan. (2013). Predicting counterproductive work behavior from guilt proneness. Journal of Business Ethics, 114(1), 45-53.

Cohen, Wolf, Panter, \& Insko. (2011). Introducing the gasp scale: A new measure of guilt and shame proneness. J Pers Soc Psychol, 100(5), 947-966.

Cotte, J., Coulter, R. A., \& Moore, M. (2005). Enhancing or disrupting guilt: The role of ad credibility and perceived manipulative intent. Journal of Business Research, 58(3), 361368.

Coulter, R. H., \& Pinto, M. B. (1995). Guilt appeals in advertising - what are their effects. Journal of Applied Psychology, 80(6), 697-705.

Dahl, D. W., Honea, H., \& Manchanda, R. V. (2003). The nature of self-reported guilt in consumption contexts. Marketing Letters, 14(3), 159-171.

Dahl, D. W., Honea, H., \& Manchanda, R. V. (2005). Three rs of interpersonal consumer guilt: Relationship, reciprocity, reparation. Journal of Consumer Psychology, 15(4), 307-315.

Fischhoff, B., Gonzalez, R. M., Small, D. A., \& Lerner, J. S. (2003). Judged terror risk and proximity to the World Trade Center. Journal of Risk and Uncertainty, 26(2-3), 137151.

Gans, J. S., \& Groves, V. (2012). Carbon offset provision with guilt-ridden consumers. Journal of Economics \& Management Strategy, 21(1), 243-269.

Goldsmith, K., Cho, E. K., \& Dhar, R. (2012). When guilt begets pleasure: The positive effect of a negative emotion. Journal of Marketing Research, 49(6), 872-881.

Han, D., Duhachek, A., \& Agrawal, N. (2014). Emotions shape decisions through construal level: The case of guilt and shame. Journal of Consumer Research, 41(4), 1047-1064.

Hanks, L., \& Mattila, A. S. (2014). The impact of gender and prepurchase mood on consumer guilt after a travel purchase. Journal of Travel Research, 53(5), 625-637.

Holbrook, M. B., \& Batra, R. (1987). Assessing the role of emotions as mediators of consumer responses to advertising. Journal of Consumer Research, 14(3), 404-420.

Hur, J., \& Jang, S. (2015). Anticipated guilt and pleasure in a healthy food consumption context. International Journal of Hospitality Management, 48, 113-123.

Jones, W. H., Schratter, A. K., \& Kugler, K. (2000). The guilt inventory. Psychological Reports, 87(3_suppl), 1039-1042.

Kayal, G. G., Simintiras, A. C., \& Rana, N. P. (2017). Investigating gender differences in consumers' experience of guilt: A comparative study. Journal of Retailing and Consumer Services, 39, 71-78.

Kleine, R. E., Schultzkleine, S., \& Kernan, J. B. (1992). Mundane everyday consumption and the self - a conceptual orientation and prospects for consumer research. Advances in Consumer Research, 19, 411-415.

Kollmuss, A., \& Agyeman, J. (2002). Mind the gap: Why do people act environmentally and what are the barriers to pro-environmental behavior? Environmental education research, 8(3), 239-260.

Koufaris, M. (2002). Applying the technology acceptance model and flow theory to online consumer behavior. Information systems research, 13(2), 205-223.

Kroll, J., \& Egan, E. (2004). Psychiatry, moral worry, and the moral emotions. Journal of Psychiatric Practice®, 10(6), 352-360. 
Kugler, K., \& Jones, W. H. (1992). On conceptualizing and assessing guilt. J Pers Soc Psychol, 62(2), 318-327.

Lascu, D. N. (1991). Consumer guilt - examining the potential of a new marketing construct. Advances in Consumer Research, 18, 290-295.

Lazarus, R. S. (1991). Progress on a cognitive motivational relational theory of emotion. American Psychologist, 46(8), 819-834.

Lee-Wingate, S. N., \& Corfman, K. P. (2010). A little something for me and maybe for you, too: Promotions that relieve guilt. Marketing Letters, 21(4), 385-395.

Lewis, M. (1997). The self in self-conscious emotions. Self across Psychology: SelfRecognition, Self-Awareness, and the Self Concept, 818, 119-142.

Mattila, A. S., Hanks, L., \& Zhang, L. (2013). Existential guilt and preferential treatment: The case of an airline upgrade. Journal of Travel Research, 52(5), 591-599.

Miao, L. (2011). Guilty pleasure or pleasurable guilt? Affective experience of impulse buying in hedonic-driven consumption. Journal of Hospitality \& Tourism Research, 35(1), 79101.

Newman, K. P., \& Trump, R. K. (2017). When are consumers motivated to connect with ethical brands? The roles of guilt and moral identity importance. Psychology \& Marketing, 34(6), 597-609.

Nyer, P. U. (1997). A study of the relationships between cognitive appraisals and consumption emotions. Journal of the Academy of Marketing Science, 25(4), 296-304.

Onwezen, M. C., Antonides, G., \& Bartels, J. (2013). The norm activation model: An exploration of the functions of anticipated pride and guilt in pro-environmental behaviour. Journal of Economic Psychology, 39, 141-153.

Onwezen, M. C., Bartels, J., \& Antonides, G. (2014a). Environmentally friendly consumer choices: Cultural differences in the self-regulatory function of anticipated pride and guilt. Journal of Environmental Psychology, 40, 239-248.

Onwezen, M. C., Bartels, J., \& Antonides, G. (2014b). The self-regulatory function of anticipated pride and guilt in a sustainable and healthy consumption context. European Journal of Social Psychology, 44(1), 53-68.

Orth, U., Robins, R. W., \& Soto, C. J. (2010). Tracking the trajectory of shame, guilt, and pride across the life span. J Pers Soc Psychol, 99(6), 1061.

Peloza, J., White, K., \& Shang, J. (2013). Good and guilt-free: The role of self-accountability in influencing preferences for products with ethical attributes. Journal of Marketing, 77(1), 104-119.

Ratchford, B. T. (1987). New insights about the fcb grid. Journal of Advertising Research, 27(4), 24-38.

Roseman, I. J. (1991). Appraisal determinants of discrete emotions. Cognition \& Emotion, 5(3), 161-200.

Roseman, I. J., Wiest, C., \& Swartz, T. S. (1994). Phenomenology, behaviors, and goals differentiate discrete emotions. J Pers Soc Psychol, 67(2), 206.

Saintives, C., \& Lunardo, R. (2016). How guilt affects consumption intention: The role of rumination, emotional support and shame. Journal of Consumer Marketing, 33(1), 4151.

Soscia, I. (2007). Gratitude, delight, or guilt: The role of consumers' emotions in predicting postconsumption behaviors. Psychology \& Marketing, 24(10), 871-894.

Steenhaut, S., \& Van Kenhove, P. (2006). The mediating role of anticipated guilt in consumers' ethical decision-making. Journal of Business Ethics, 69(3), 269-288.

Tangney, J. P., Miller, R. S., Flicker, L., \& Barlow, D. H. (1996). Are shame, guilt, and embarrassment distinct emotions? J Pers Soc Psychol, 70(6), 1256-1269. 
Tangney, J. P., Stuewig, J., \& Mashek, D. J. (2007). Moral emotions and moral behavior. Annual Review of Psychology, 58, 345-372.

Theotokis, A., \& Manganari, E. (2015). The impact of choice architecture on sustainable consumer behavior: The role of guilt. Journal of Business Ethics, 131(2), 423-437.

Tracy, J. L., \& Robins, R. W. (2004). Putting the self into self-conscious emotions: A theoretical model. Psychological Inquiry, 15(2), 103-125.

Tracy, J. L., \& Robins, R. W. (2006). Appraisal antecedents of shame and guilt: Support for a theoretical model. Personality and Social Psychology Bulletin, 32(10), 1339-1351.

Zemack-Rugar, Y., Bettman, J. R., \& Fitzsimons, G. J. (2007). The effects of nonconsciously priming emotion concepts on behavior. J Pers Soc Psychol, 93(6), 927-939. 